This is an author produced version of a paper published in Technology, Pedagogy and Information. This paper has been peer-reviewed but does not include the final publisher proof-corrections or journal pagination.

Citation for the published paper:

Karaseva, Agnese; Pruulmann-Vengerfeldt, Pille; Siibak, Andra. (2018).

Relationships between in-service teacher achievement motivation and use of educational technology : case study with Latvian and Estonian teachers. Technology, Pedagogy and Information, vol. 27, issue 1, p. null

URL: https://doi.org/10.1080/1475939X.2017.1339633

Publisher: null

This document has been downloaded from MUEP (https://muep.mah.se) / DIVA (https://mau.diva-portal.org). 


\section{Relationships between in-service teacher achievement motivation and use of educational technology: case study with Latvian and Estonian teachers}

This study explored the relationship of in-service teacher achievement goal orientation and practices of educational technology use. Semi-structured individual interviews with secondary school teachers in Latvia $(\mathrm{N}=16)$ and Estonia $(\mathrm{N}=10)$ revealed that the use of ICT in pedagogical work and the ways in which teachers learn ICT-related skills are associated with individual differences in teacher achievement goal orientation. Based on our findings, we argue that achievement goal theory is a promising framework for understanding how the integration and application of ICT in teaching happens. Directions for future research and implications for teacher training are discussed.

Keywords: pedagogic use of ICT; teacher motivation; achievement goal orientation; secondary school teachers

\section{Introduction}

Secondary school teachers are often criticised for not making effective use of information and communication technology (ICT) (Aldunate \& Nussbaum, 2013). Recently various teacher beliefs have been extensively investigated as potential reasons for the slow uptake of ICT in pedagogic practice (Karaseva, Siibak, \& PruulmannVengerlfeldt, 2015; for an extended review see $\mathrm{Fu}, 2013)$. However, one crucial teacher-level factor strongly associated with overall instructional choices and behaviour has been left largely unexamined: teacher achievement motivation (Kucsera, Roberts, Walls, Walker, \& Svinicki, 2011; Retelsdorf, Butler, Streblow, \& Schiegele, 2010). Additionally, to the best of our knowledge no studies have examined relationships of teachers`achievement goal orientation and ICT integration in teaching.

Hence, our exploratory study contributes to the understanding of how different achievement goals are related to the motivation of some teachers to experiment with 
new teaching approaches and tools, while other teachers hardly make any effort to implement innovations, or quickly abandon them (Cave \& Mulloy, 2010). This topic is worth exploring considering that teachers` choices regarding technology use and application of different tools, as argued by Rieger (2009), are always "nested" activities, i.e. integrated into overall teachers ' professional strivings, and performed in order to achieve particular goals.

While we are aware that research on teachers` achievement motivation has been criticised as being too focused on relatively short-term goals, which may reduce opportunities to understand teacher motivation more broadly (e.g., see Mansfield, Wosnitza \& Beltman, 2012), we believe that investigating achievement goals helps to shed more light on ICT adoption for educational purposes. We believe that an increased focus on teacher achievement orientation leads to a better understanding of what motivates in-service teachers to learn and adopt new professional knowledge (Beijaard, Korthagen, \& Verloop, 2007; Ng, 2010), thus supporting the development of more effective continuous teacher training on ICT applications in education that meet the needs of learners in the 21 st century (Webb, 2014).

The purpose of the present study is to explore relationships between different teacher achievement goals and the ways in which teachers integrate technology in their practices, and how teachers adopt new knowledge and skills related to ICT use.

\section{Theorising about teacher achievement motivation}

\section{Achievement motivation frameworks}

Achievement motivation generally is defined as "the energization and direction of competence-based affect, cognition, and behaviour" (Elliot, 1999:169). This article focuses on one aspect of achievement motivation - achievement goal orientation - as 
previous studies have shown that achievement goals create distinct motivational systems which are associated with qualitative differences in the ways people define and evaluate professional success, and regulate behaviour (for review, see Butler, 2000). Achievement goals are defined as the reasons for engaging in a task (Dweck \& Legget, 1988). Achievement goals are often conceptualized as rather stable orientations toward the achievement of particular results, and are: a) focused on an object, b) used to direct or guide behaviour, c) focused on the future, d) internally represented, and e) something the individual is committed to approach or avoid (Hulleman, Schrager, Bodmann, \& Harackiewicz, 2010; Linnenbring \& Pintrich, 2003). Elliot and Dweck (1988:1) argue that each achievement goal "runs off a different program" of motivation, reasoning and behaviour. Hence, achievement goals and associated processes are seen as interrelated in a broad schema that determines how people approach a situation and respond to it (Hulleman et al., 2010).

Achievement goals of students have been studied for a long time (see Elliot, 2005, for review), originally distinguishing between four types of achievement goals: the mastery goal, two types of ability goals, ability-approach and ability-avoidance goals, and the work-avoidance goal. The mastery goal is characterised as a focus on personal growth, striving to acquire and improve skills and understanding, and the development of academic competence, while ability goals are seen as directed towards demonstrating superior academic competence or hiding inferior academic ability (Dweck \& Legget, 1988). The work-avoidance goal reflects endeavours to go through a school day with as little effort as possible (Nolen, 1988). Recently, a social relationship goal has been added as the fifth distinctive type of achievement motivation in academic settings and predictor of particular behaviour, and it involves strivings for affiliation and popularity or attempts to avoid rejection (Ryan \& Shim, 2008). 
Very recently, the achievement goal theory has started to gain attention as a useful framework to be applied in teaching (Butler 2007; Kucsera et al., 2011; Ng, 2010). Researchers claim that schools are "achievement arenas" (Butler, 2007:242) not only for students but also for teachers who want to succeed in their jobs (Ames \& Ames, 1984). However, teachers vary as to the extent to which they endorse different types of achievement goals (Cave \& Mulloy, 2010; Cho \& Shim, 2013).

Nevertheless, teacher achievement goals frameworks are largely derived from student studies. Most often the triadic model of mastery, ability-approach and abilityavoidance goals (see, e.g., Kucsera et al., 2011; Murayama, Elliot, \& Yamagata, 2011; $\mathrm{Ng}, 2010$ ) is used, or in some cases a four-element model is applied, with the workavoidance goal added (see Fasching, Dresel, Dickhäuser, \& Nitsche, 2010). Butler (2012) has proposed and further examined (Butler \& Shibaz, 2014) the broadest framework so far; it includes five types of achievement goals, all of which have been identified previously in the area of student motivation. In Butler`s model, teachers are seen as striving either: 1) to acquire and improve professional competence (mastery orientation), or 2) to prove that they have superior abilities in teaching (ability-approach orientation), or 3) to avoid the demonstration of insufficient ability (ability-avoidance orientation), or 4) to get through the day with less effort (work-avoidance orientation), or 5) to create close and caring relationships with their students (relational goal orientation) based on the notion that teaching is an "interpersonal rather than only a personal endeavour" (Butler, 2012:42). Previous research reveals that teachers` achievement goals have links to instructional behaviour and classroom process, although very few aspects have been examined so far, e.g. teachers` openness to students questions and seeking help (Butler \& Shibaz, 2008), student motivation to 
study (Dresel, Fasching, Steuer, Nitsche, \& Dickhäuser, 2013), and classroom goals that teachers create for their students (Retelsdorf et al., 2010; Shim, Cho, \& Cassady, 2013).

Teacher achievement goal orientation is understood as multifaceted and complex. A teacher can pursue multiple goals simultaneously (Woolfolk Hoy, 2008). The multiple goal perspective (Harackiewicz, Barron, Pintrich, Elliot, \& Thrash, 2002) proposes that people in academic contexts do not merely adopt one form of achievement goal; instead, individuals try to achieve a combination of goals simultaneously, or switch from one goal to another depending on the situation (Harackiewicz et al., 2002; Linnenbrink, 2005; Midgley, Kaplan, \& Middleton, 2001; Pintrich, 2000). The multiple goal perspective is a relevant framework for analysing teacher achievement orientation more broadly (Malmberg, 2008), especially when considering the increasing pressure on teachers to demonstrate success on multiple dimensions, e.g. following curriculum standards and preparing students for proficiency tests (Shim et al., 2013).

\section{Achievement goal orientation and teacher learning}

The development of professional skills is viewed as an essential part of teaching (Paulick, Retelsdorf, \& Möller, 2013). Teacher achievement goals relate to the ways in which teachers benefit from training (Van Eekelen, Vermunt, \& Boshuizen, 2006). Teacher learning does not happen only by taking part in formal training (Hoekstra, Beijaard, Brekelmans, \& Korthagen, 2007); it can also take place in different situations at work (Järvelä \& Järvenoja, 2011) and may involve a range of social and behavioural strategies. Hence, in our current study we interpret acquisition of new knowledge and adoption of ICT skills as a broad range of activities: participation in formal learning, involvement in informal teacher networks for experience sharing, observation of other teachers` practices, exchanging teaching materials etc. Previous research indicates that 
teachers with mastery goal orientation are more willing to adopt new approaches and teaching methods due to their intrinsic motivation, whereas the ability-approach orientation promotes interest in learning if it brings some kind of external rewards later in the form of appreciation and approval (Gorozidis \& Papaioannou, 2011; Ng, 2010; Retelsdorf et al., 2010). Butler (2007) has indicated that teachers with mastery goal orientation seek help in ways that support the acquisition of new knowledge, whereas teachers with work-avoidance orientation seek ready solutions or prefer others to solve their problems. Some studies indicate that teachers with ability goals might perceive the seeking of help as a sign of incompetence and therefore they avoid asking for help (Nitsche, Dickhäuser, Fasching, \& Dresel, 2011).

\section{Research questions of the study}

In the present study, we explored relationships between different types of teacher achievement goal orientation, and 1) the ways in which teachers integrate technology into their practices and 2) the ways in which teachers acquire new knowledge about educational technology and develop ICT-related skills.

Our study was informed by the following research questions:

-How do teachers with different achievement goal orientation integrate technology into their practices?

-How do teachers with different achievement goal orientation learn about ICT and adopt new ICT-related skills?

\section{Methods}

Our data derive from two separate studies focused on secondary school teachers`goal 
orientation and experience in using different educational technology. The first study was conducted in autumn 2012 in Estonia, and the second one in spring 2013 in Latvia. Here we report the parts of the studies which focused on teacher goal orientation.

\section{Sample}

Our sample consisted of 26 participants: 10 teachers of different subjects from five Estonian- or Russian-speaking schools around Estonia and 16 teachers of different subjects working in a middle-sized school ( $~ 500$ students $)$ in a regional town in Latvia. Both countries serve as interesting examples in studying pedagogic use of ICT, because since regaining independence in 1991 there have been strivings for a general education curriculum that focuses on integration of ICT in every school subject (Empirica, 2014; Grivins, 2012). Subsequently, large-scale teacher training programmes have been carried out over years and considerable investment spent in school equipment, however, still many teachers question the role of ICT in their teaching (Karaseva et al., 2015).

In the process of selecting participants for our study, we aimed for diversity and saturation. First, our aim was to capture as wide variety of practices related to use of educational ICT tools as possible, and, second, we were guided by the existing achievement goal framework proposed by Butler $(2007,2012)$ as the frame of reference in the selection process. In the Latvian school where this study was conducted as part of a larger project (see Karaseva, 2016) the vice-headmaster responsible for ICT development was asked to suggest teachers who teach the same subject (e.g., English as foreign language), but represent different attitudes and practices of ICT integration in their teaching. On second step, individual consent to participate in the study was asked from the recommended teachers. For choosing participating schools and teachers in Estonia, one of the criteria was involvement in training programs and activities 
organized by the Tiger Leap Foundation (Runnel, Pruulman-Vengerfeld, \& Reinsalu, 2009). We differentiated between schools which had been quite active in taking part in various ICT related initiatives organized by the Foundation, schools that had taken part in some of those activities, and schools whose teachers had no connection to ICTrelated training courses and activities. Schools were asked to suggest one teacher of humanities and one of sciences from their school who were accustomed to using ICTs in everyday teaching, and would be willing to participate in the study. The chosen approach ensured that the final simple was heterogeneous in terms of teaching experience, subjects taught, and the practices and attitudes towards ICT integration in teaching. In the Estonian group, teaching experience ranged from three to 20 years, and in the Latvian sample it ranged from 11 to 33 years. In the final sample all but one respondent was female. The study participants taught at basic and secondary levels (grades 7-12). Table 1 gives an overview of our sample.

Table 1. Overview of the Sample.

[Table 1 to be inserted here].

\section{Data collection}

Hour-long individual semi-structured interviews focused on various topics related to technology integration in pedagogic practice were carried out. In the current study we focused on the following topics: (a) the reasons teachers decide to integrate ICT into their work, (b) what motivates teachers to choose or avoid particular tools and approaches to technology use (c) the perceived positive and negative aspects related to technology use in education, (d) where and how teachers learn about new tools or approaches to ICT use, and whom they consult for troubleshooting, (e) what goals 
teachers pursue in their work, (f) what, in teachers' opinions, is a good and successful teacher, and according to what criteria teachers evaluate their own success at work, and (g) if and how the feeling of being successful in pedagogic work is related to technology use. We asked questions about what makes teachers feel successful in their job because Butler $(2007,2012)$ used the phrase "I would feel most successful as a teacher (...)" as the opening of several of the items in her measurement scale. Relations between feeling successful and achievement motivation were examined in the classic study of Nicholls, Patashnick and Nollen (1985), who found that among students ability orientation was associated with the belief that success in the academic setting was related to extrinsic factors, such as impressing others or being competitive, while mastery orientation was associated with the belief that success was achieved by trying to understand things deeply, being interested in what you do, working hard, cooperating with others etc. (Nolen, 1988).

We applied qualitative interview method in our study aiming to complement the existing body of knowledge which is mainly built on quantitative studies. Particularly our chosen approach was guided by the need to enrich our understanding about teacher strivings to coordinate the achievement of multiple goals in relation to their professional practice, in our case, - pedagogic use of ICT.

\section{Limitations of sampling and data collection}

We acknowledge that the samples in both countries were different and not representative. Hence, we avoid comparing our samples and making any cross-national claims. Furthermore, we are aware of the fact that there was a six-month time gap between the interviews. However, relying on the argument by Kagan (1992) that teacher intrinsic factors tend to be consistent over time, we do not believe that this time gap had 
a significant effect on our findings. Considering that there are a limited number of studies on teacher motivation, we believe that our exploratory multi-case study provides valuable input in helping to define questions and directions for future research (Yin, 1993).

\section{Data analysis}

We applied a deductive approach in our data analysis. In the data coding process, we aimed to explore relationships between teachers` achievement goal orientation and their ICT practices and the adoption of new knowledge and skills of ICT use. Therefore, we made use of the existing achievement goal framework proposed by Butler $(2007,2012)$ as the frame of reference. We did initial coding to split our interview material into smaller units and then continued with close reading and case analysis, specifically looking for themes and patterns in teachers` responses related to 1) their achievement goal orientation, 2) patterns of ICT integration in their practices and 3) the ways in which teachers adopt new knowledge, methods and ICT tools in their teaching.

Furthermore, we compared the excerpts from our interviews to the items that were used in the surveys in previous studies of teacher achievement goal orientation (Butler, 2007, 2012) to identify matching themes indicating the various types of motivation (examples from the data coding scheme are provided in Table 2).

Table 2. Example of the data coding scheme.

[Table 2 to be inserted here].

Later we did cross-case analysis by comparing and contrasting all of the individual teachers in our sample in order to find similarities and differences between teachers' utterances. As there was significant ambiguity in the data coding, several 
discussion sessions between researchers were held before the coding of all cases was finalised. We found that in some cases teachers did not pursue a single achievement goal but two goals in their work. We found two combinations of achievement goals to be present in our data: the ability-approach goal combined with the work-avoidance goal, and the mastery goal combined with the relational goal. Table 3 gives an overview of the representation of the various achievement motivation goals in our sample.

Table 3. Overview of the representation of the achievement goals in the sample.

[Table 3 to be inserted here].

In the next session we present the most important results of our study.

\section{Results}

In this section, we present results of our data coding: the different achievement goal orientations of teachers in relation to their ICT usage practices, and the various modes of adoption of new knowledge and ICT-related skills.

\section{Teachers with mastery goal orientation: ICT usage and learning practices}

Teachers who pursued mastery goals believed that technology led to much-needed change both in teaching and learning practices because it allowed more independent and deeper subject learning. As one of them said during the interview:

"For me it is important to demonstrate how biology as a subject is related to real life. Students collect lots of data by themselves, do small research projects, search online, compare information and analyse. Students publish the results of projects in a blog platform. When you work with technology, it causes a lot of noise in the classroom sometimes. Many teachers don't like this. They want peace and silence in the classroom. In my classes it is different: students discuss and work in groups. It looks like a real mess sometimes [laughs]. It is not my aim that they [students] mechanically memorize things. I want them to understand" (Teacher of biology). 
As can be seen from the excerpt, the respondents' teaching practices were based on open-ended tasks which required active student involvement, use of the Internet, and the application of various software and hardware for research, as well as data collection and production of original digital content. Furthermore, this teacher of biology was also an active mediator of students' ICT skills, e.g. instructing them how to create a blog, or how to use different software. As the example below suggests, the teachers with mastery goal orientation showed enthusiasm and intrinsic interest in experimenting with various tools and teaching methods:

"I don't like to stick to something and then repeat it over and over every year. Of course, every year there is a new group of students, but it is more for myself, not to feel bored, like, to think, ahhh, that I'm going to class again with the same thing as last year" (Teacher of Russian).

In order not to get bored, teachers with mastery goal orientation reported being frequently engaged in technology-related training. They were able to describe what specific competences they planned to improve in the near future, as in the following example:

"I have attended many courses and training sessions on ICT, but I still want to learn a lot, e.g. at the moment I am interested in learning how to work better with the interactive white board" (Teacher of chemistry).

Another characteristic for teachers with the mastery approach was that they felt that they had accumulated enough broad experience in ICT use so that they could share it with their colleagues. Some of the teachers in this group said that they often tried to urge other teachers to change their attitudes and become more active users of technology. 


\section{Teachers with the ability-approach goal: ICT usage and learning practices}

Teachers who pursued ability-approach goals reported using various technologies in almost every lesson, although they preferred ways of employing ICT that supported teacher-centred learning. Technology for them seemed to be mainly a presentation tool, a tool for performing drill-and-practice tasks, or a reward tool for students after completing tests, as in this excerpt:

"We language teachers become nice and friendly only after final exams, never before. After exams, of course, I allow students to watch some videos and other stuff during classes. ICT in my class appears only as a dessert" (Teacher of English as foreign language).

This teacher also emphasized that students`achievement on exams was the main criterion for measuring her pedagogic success. It was also a common feature for other teachers in this group. As our interview materials indicate, the use of ICT was adjusted to increase student scores on tests. One of the study participants explained that technology in her practice served to support the acquisition of particular subject knowledge that the teacher knew would be tested on an exam. Another characteristic feature for teachers in this group was that they compared their ICT handling skills to the skills of their colleagues, as in the two following excerpts from the interviews:

\footnotetext{
"I make short videos by myself. This is a new trend, I have noticed. (...) Only a few other teachers make their own videos, as far as I know" (Teacher of Latvian).

"Other teachers struggle too much to prepare for lessons; they make all the worksheets by themselves, but I know where to find ready materials online" (Teacher of mathematics).
}

Advanced ICT skills and extensive use of ICT tools for them seemed to be important elements in building the image of a "successful teacher" who is often asked 
for advice and help in ICT-related matters. Teachers also emphasized that they possessed above average ICT skills, as in the following excerpt:

"When I attend courses, some teacher training about computers, I always feel good, because I already know much of what is being told and shown" (Teacher of physics and natural sciences).

Due to their advanced skills, teachers in this group were also rather picky in selecting training opportunities: they wanted to acquire some special knowledge which not all teachers might have, e.g. how to make videos. Based on our findings, we argue that the ability approach might motivate teachers to engage actively in technologyrelated professional development, because it would be impossible to prove superior ability without actually having some advanced skills.

\section{Teachers with work-avoidance goal orientation: ICT usage and learning practices}

Similar to teachers with the ability-approach goal orientation, teachers with workavoidance goals also used technology for drill-and-practice and repetition tasks. However, teachers with work-avoidance orientation clearly emphasized that they relied on extensive use of digital resources because ICT allowed them to save time and effort during the lessons, e.g. in grading students` work or performing other tasks. Therefore, teachers in this group said that they often searched and collected ready-made study materials, drill tasks or exams online with instant automatic feedback. One of the respondents explained:

\footnotetext{
"If you have something ready, then it is so much easier to conduct the class; if you have something prepared in advance, then you just take it and use it" (Teacher of physics).
} 
This teacher explained that the time investment in finding, selecting and saving digital materials paid off later, because the workload during the days of teaching decreased. This was also one of the reasons why some teachers in this group were very much interested in exchanging ready-made materials and useful online links with other teachers, rather than developing their ICT skills. Getting access to ready-made teaching materials for one teacher in this group was an important aspect in keeping in contact with other teachers:

"As a language teacher, you must search for good materials all the time. There is nothing ready and waiting for you. (...) I know many language teachers from different projects, and when we speak on Skype or write on Facebook, I often ask them if they have found any interesting materials recently, which sites they are using for teaching a topic, and so on. If you send some of your materials in exchange, they are always happy to share with you" (Teacher of English as a foreign language).

A few teachers in this group mentioned that they wanted to improve their online information retrieval skills to perform more efficient searches. However, such a stance was characteristic only for humanities teachers, who seemed to make use of mainly generic online content, while science teachers reported the usage of digital platforms developed specifically to support their subject teaching.

\section{Teachers with relational goal orientation: ICT usage and learning practices}

As Table 2 indicates, teachers with relational goal orientation expressed a desire to have a close relationship with their students and to develop an informal and friendly atmosphere in class. In fact, we found the relational goal orientation to be very common among our respondents, e.g. in the Latvian sample five out of 16 study participants said that having a good and informal relationship with students was the main achievement goal for them. Teachers talked about various techniques to ensure achievement of this 
goal.

For example, a teacher of music said that she often asked students to help out with troubleshooting, or with finding information on the Internet. With this her aim was to position herself as being "equal" to her students and to make the atmosphere in the class more informal and friendlier. Another teacher said that she asked students to help with ICT with a particular aim:

“(...) to show them [students] that the teacher is not always the clever one...

Students like it, you know; they like to help, and it is a pleasure for them to see that I also don't know something...” (Teacher of German as a foreign language).

Teachers in this group often claimed to use ICT tools mainly at the end of the lesson for five or ten minutes, after they had already covered the topic. In these cases, ICT was used mainly to illustrate a topic with a video or some other material from the Internet. Furthermore, as they had no intention of using ICT more actively, the teachers in this group were quite satisfied with their perceived medium or basic ICT skills and expressed little motivation to improve these skills. For instance, one of our respondents belonging to this group claimed that she had attended some technology training only because she needed a certificate to get a promotion.

\section{Teachers with ability-avoidance goal orientation: ICT usage and learning practices}

There were only two teachers among our study participants who had the abilityavoidance goal orientation (one in the Latvian and one in the Estonian sample). Despite the fact that both of the teachers belonging to this group evaluated their ICT skills as being very low, their attitudes towards ICT were notably different. One of them reported actually being an active ICT user, with a positive attitude towards technology. 
In order not to appear incompetent in front of her students, she carefully selected tools and resources she used in class:

"This varies; there are classes which are very strong, where I feel the need to hide as much as I can that I know so little, yet there are also classes which are very weak" (Teacher of history and social sciences).

For the above reason, she was also an enthusiastic participant in different ICTrelated training courses.

The other teacher sharing the ability-avoidance motivation, however, believed that "live" discussions in the classroom and writing by hand were the best methods for learning a new language. Thus, she expressed her doubts about the educational value of ICT. She used technology mainly for administrative purposes and record keeping. During the interview she said:

“../ I am not going to stay up all night searching for something on the Internet, and then the next day feel delighted with what I have found... No, this is not for me" (Teacher of English as a foreign language).

Due to her negative attitude toward technology, the teacher was not motivated to improve her ICT skills and engage in training activities.

\section{Combination of achievement goals and ICT use}

In our sample, we found two combinations of teachers`achievement goals: (a) the ability-approach goal combined with the work-avoidance goal, and (b) the mastery goal combined with the relational goal. One remarkable example in our sample of pursuing simultaneous ability-approach and work-avoidance goals was a teacher of mathematics who emphasized that for her it was important that her technological abilities, especially information retrieval skills, be higher than her colleagues' skills: 
"I know where [on the Internet] to find what I need. Many teachers don't know how to work with the Internet."

She also spent a lot of time before lessons selecting and preparing digital teaching materials to reduce her workload during teaching. Her students often did online drill-and-practice tasks or frequent tests in the computer lab without her needing to intervene in their learning much.

\footnotetext{
"Before classes I make very detailed worksheets so that we can work efficiently with the computers later. Then I don't have to explain everything to every student, and I don't have to answer all those questions; they have all of the necessary information on the worksheets, everything explained step by step" (Teacher of mathematics).
}

Other teachers with combined ability-approach and work-avoidance motivation generally relied on pre-defined tasks, which, as is illustrated in the interview excerpt above, ensured "efficient" completion of the tasks. Such teachers, on the one hand, seemed to be willing to use various types of ICT in their teaching but, on the other hand, showed concern that "too much" technology would cause discipline problems in class, impeding them from keeping up with the curriculum. Strict regulations on what students were allowed to do with technology in their lessons seemed the key for them to avoid such problems.

The second combination of the achievement goals was the relational goal coupled with the mastery goal. Teachers in this group valued the acquisition of deep knowledge in their subject, and emphasized that they also strove to develop and maintain good relationships with students. Caring about students`emotional well-being was a characteristic that we did not find among teachers with pure mastery goal orientation. In one example from the interview, one of our study participants promoted 
the progress of each individual student, which is characteristic of mastery goal orientation:

"I can give a good grade for just trying, for attitude. Maybe it is the first time the student does something right. He will remember it and try much harder the next time" (Teacher of arts and housekeeping for girls).

Later she explained that her aim was to create a friendly relationship with her students, which was achieved by creating an atmosphere where students felt good:

"It is very important to create an environment where students are not afraid to ask questions. I know from my experience at school that when you have a question you are often too afraid to ask your teacher. It is important to have a dialogue in the classroom. The teacher cannot be the superior person; students should not feel like that. A good teacher should admit her mistakes and apologise. Students really value this. Is it correct to work in this way? I don't know. It is my way of doing things" (Teacher of arts and housekeeping for girls).

We noticed that teachers who pursued the combination of relational and mastery goals did not restrict their uses of technology based on relational concerns, as did the teachers with pure relational goal orientation. Quite the contrary: their teaching approaches were based on creative and interactive learning that involved plenty of technology use. They also practised communication online with their students, which was not characteristic of teachers with pure relational goal orientation.

\section{Discussion}

This exploratory study focused on an under-researched area in the field of educational technology, namely, the relationship between teachers` ICT integration practices and their achievement goal orientations. By applying the teacher achievement goal framework proposed by Butler $(2007,2012)$, we examined, in particular, how teachers 
use different ICTs in their practices, and how teachers adopted new knowledge and learned ICT-related skills. Based on the results of our study, we argue that teacher achievement goal orientation is strongly associated with practices of pedagogical ICT use.

Based on our findings, we agree with Ottenbreit-Leftwich, Glazewski, Newby and Ertmer (2010) that teacher training needs and willingness to be involved in professional development are closely linked to teachers `visions of what they want to achieve in their profession, and to perceptions of what knowledge is beneficial for improving their practices. In fact, our findings suggest that mastery goal orientation might predict more active involvement in teacher training: our study participants with mastery goal motivation were the most eager learners in our sample, demonstrating a readiness to adopt new knowledge and skills based on their interests and passion for technology. The fact that they could find enjoyment in improving their mastery of ICT by taking part in almost any kind of learning activity also had a significant effect on their class ICT usage practices, which is a characteristic emphasized in some previous studies (e.g., Dresel et al., 2013). In addition we support the findings of previous studies which found the mastery motivation to be the most adaptive form of achievement goal for involvement in teacher training (Gorozidis \& Papaioannou, 2011; Ng, 2010; Retelsdorf et al., 2010).

Similar to the results of previous research (Plank \& Condliffe, 2013; Popham, 2001), our findings reveal that teachers with ability-approach orientation were motivated to use ICT so as to prepare students for taking high-stakes exams, whereas for teachers with work-avoidance goal orientation ICT tools were primarily used to reduce workload (Selwood \& Pilkington, 2005). Furthermore, work-avoidance goal orientation was related to intentions to get involved in teacher professional development 
with the expectation of benefiting from ready-made solutions (Butler, 2007; Nitsche et al., 2011). However, although Maehr and Zusho (2009) have argued that workavoidance among students can be viewed as a maladaptive learning strategy, our results indicate that in the teacher sample this is not the case. According to our findings, teachers with work-avoidance goal orientation actually spent a considerable amount of time in preparing teaching materials before the lessons in order to minimize the in-class workload. Therefore, our results support the claim of Retelsdorf et al. (2010) and Butler (2007), who argued that even committed teachers welcome free periods during a teaching day, and appreciate the option of using ready-made materials.

Teachers with ability-approach goal orientation, however, strove to keep their ICT skills in line with the "good, efficient teacher" image that they tried to build. Thus, our findings echo the results of $\mathrm{Ng}$ (2010), suggesting that ability-approach goal orientation promotes interest in learning, which leads to external rewards later, e.g. in the form of appreciation and approval.

In comparison with previous research which stresses the positive aspects of the relational orientation, which is associated with teachers` responsiveness to students` questions, provision of support and help (Butler, 2007), our findings suggest that achievement motivation is a crucial factor that determines how and whether teachers have benefited from engagement in professional development of the pedagogic use of ICT. In other words, our findings demonstrate that sometimes intrinsic factors, such as a teacher`s orientation towards relational goal achievement, limit the teacher`s interest in technology and its application in teaching practice. In fact, we argue that teachers with relational motivation might not fully support the integration of digital skills and competences which, according to policy goals, students in Latvia and Estonia are supposed to learn along with subject knowledge (Mägi, 2006; Kangro \& Kangro, 2004). 
Taking into consideration the fact that relational goals are very common among preservice teachers (Thomson \& McIntyre, 2013) and are often actually reported as one of the main reasons why people decide to enter the teaching profession (Watt \& Richardson, 2008), the question arises: to what extent is it possible to acquire such skills in an environment where ICTs might be perceived as disturbing and therefore largely unwelcome? We argue that a balance in teacher training programmes should be sought involving different prospective teachers` aims to create close relationships with their future students, and an understanding of how technology actually can promote the achievement of relational goals.

In fact, it is important for teachers to learn how their goals, values and motivation may affect their teaching and instructional practices. Therefore, we support the idea of Retelsdorf and Günther (2011) that teacher trainers should pay more attention to the enhancement of teachers' mastery orientation during teacher education and in-service training. Our study provides an in-depth look at the complex of factors that influence in-service teachers' thinking about their motives for being involved in professional training. As our findings reveal, training can be understood as a broad range of activities. i.e. not only as the involvement in formal teacher training (Hoekstra, Beijaard, Brekelmans, \& Korthagen, 2007), but also as experience exchange, participation in informal networking, observation of colleagues' work etc. Therefore, it is important to highlight the underlying aspects of teachers`strivings in their profession and their motivation to teach at a time when the fashion is to see teachers as rather unmotivated and struggling to find ways of meaningful application of technology in their classrooms (Ertmer, Ottenbreit-Leftwich, Sadik, Sendurur, \& Sendurur, 2012). Teachers`achievement goals form an important part of teachers`professional belief systems (Retelsdorf et al, 2010). As with all beliefs, they are resistant to change 
(Pajares, 1992). Therefore we believe that studies like ours provide a useful foundation for further examination of teacher motivation and achievement goal orientation.

\section{Conclusion}

To summarize, the present study contributes to opening up promising new ways of studying educational technology use. In contrast to the majority of studies (e.g. Linnenbrink, 2005; Harackiewicz et al., 2002) in which the multiple goal perspective has considered only mastery and ability goals, we agree with Nitsche et al. (2011) that future studies should focus on a broader spectrum of achievement goals, including relational goals, and making the distinction between ability-approach orientation and ability-avoidance orientation. It would be useful to study the coordination of multiple goals according to the achievement situation (Midgley et al., 2001): links between external factors, such as the pressure to prepare students for high-stakes exams and teacher ICT practices, should be investigated in more detail. Finally, the influences of contextual factors, (Mansfield et al., 2012) such as achievement goal orientation at the school level (Cho \& Shim, 2013), should be examined in relation to teacher ICT usage patterns, since some previous studies (e.g., Ciani, Summers, \& Easter, 2008) indicate that teachers tend to adopt the values and goals of the school environment.

Acknowledgements. This work was supported by the Estonian Research Council under Grant number PUT44.

\section{References}

Aldunate, R., \& Nussbaum, M. (2013). Teacher adoption of technology. Computers in Human Behaviour, 29(3), 519-524, DOI: 10.1016/j.chb.2012.10.017 
Ames, C., \& Ames, R. (1984). Systems of student and teacher motivation: Toward a qualitative definition. Journal of Educational Psychology: 76(4), 535-556.

Beijaard, D., Korthagen, F., \& Verlopp, F. (2007). Understanding how teachers learn as a prerequisite for promoting teacher learning. Teachers and Teaching: theory and practice, 13(2), 105-108. DOI: 10.1080/13540600601152298

Butler, R. (2000). What learners want to know: The role of achievement goals in shaping information seeking, learning, and interest. In C. Sansone \& J. M. Harackiewicz (Eds.), Intrinsic and extrinsic motivation: The search for optimal motivation and performance (pp. 161-194). San Diego, CA: Academic Press.

Butler, R. (2007). Teachers`achievement goal orientation and associations with teachers help seeking: Examining a novel approach to teacher motivation. Journal of Educational Psychology: 99(2), 241-252. http://dx.doi.org/10.1037/0022-0663.99.2.241

Butler, R., (2012). Striving to connect: Extending an achievement goal approach to teacher motivation to include relational goal for teaching. Journal of Educational Psychology, 104(3), 726-742. http://dx.doi.org/10.1037/a0028613

Butler, R. (2014). What teachers want to achieve and why it matters. An achievement goal approach to teacher motivation. In P.W. Richardson, S.A.Karabenick, H.M.G.Watt (Eds.) Teacher Motivation: Theory and Practice. Routledge: NY, 20-35.

Butler, R., \& Shibaz, L. (2008). Achievement goals for teaching as predictors of students` perceptions of instructional practices and students` help seeking and cheating. Learning and Instruction, 18, 453-467. DOI:

10.1016/j.learninstruc.2008.06.004

Butler R., \& Shibaz, L. (2014). Striving to connect and striving to learn: Influences of relational and mastery goals for teaching on teacher behaviours and student interest and help seeking. International Journal of Educational Research, 65, 4153. http://dx.doi.org/10.1037/a0028613

Cho, Y., \& Shim, S. S. (2013). Predicting teachers`achievement goals for teaching: The role of perceived school goal structure and teachers` sense of efficacy. Teaching and Teacher Education: 32, 12-21. DOI: 10.1016/j.tate.2012.12.003 
Ciani, K. D., Summers, J. J., \& Easter, M. A. (2008). A “top-down" analysis of high school teacher motivation. Contemporary Educational Psychology, 33(4), 533560. DOI: 10.1016/j.cedpsych.2007.04.002

Dresel, M., Fasching, M.S., Steuer, G., Nitsche, S. \& Dickhäuser, O. (2013). Relations between teachers' goal orientations, their instructional practices and students` motivation. Psychology, 4(7), 572-584. http://dx.doi.org/10.4236/psych.2013.47083

Dweck., C.S., \& Legget, E.L. (1988). A social-cognitive approach to motivation and personality. Psychological Review, 95, 256-273. Retrieved from: http://www.unco.edu/cebs/psychology/kevinpugh/motivation_project/resources/ dweck_leggett88.pdf

Elliot, A.J. (1999). Approach and avoidance motivation and achievement goals. Educational Psychologist, 24(3), 169-189. DOI: 10.1207/s15326985ep3403_3

Elliot, A. J. (2005). A conceptual history of the achievement goal construct. In A.J.Elliot, \& C.S.Dweck (Eds.). Handbook of competence and motivation, 16, 52-72. New York: Guilford Publications.

Elliot, A.J., \& Dweck, C.S. (1988). Goals: an approach to motivation and achievement. Journal of Personality and Social Psychology, 54(1), 5-12.

Empirica (2014).e-Skills in Europe. Estonia, The Country Report. Available at: http://eskillsmonitor2013.eu/fileadmin/monitor2013/documents/Country_Reports/Country_R eport_Estonia.pdf

Ertmer, P. A., \& Ottenbreit-Leftwich, A. T. (2010). Teacher technology change: how knowledge, confidence, beliefs, and culture intersect. Journal of Research on Technology in Education: 42(3), 255-284. Retrieved from: http://www.edci.purdue.edu/ertmer/docs/AERA09_Ertmer_Leftwich.pdf

Ertmer, P., Ottenbreit-Leftwich, A., Sadik, O., Sendurur, E., \& Sendudur, P. (2012). Teacher beliefs and technology integration practices: A critical relationship. Computers \& Education, 59(2), 423-435. 
Fasching, M. S., Dresel, M., Dickhäuser, O., \& Nitsche, S. (2010). Goal orientations of teacher trainees: Longitudinal analysis of magnitude, change and relevance. Journal for Educational Research Online, 2(2), 9-33. Retrieved from: http://www.j-e-r-o.com/index.php/jero/article/view/117/85

Gorozidis, G., \& Papaioannou, A. (2011). Teachers' self-efficacy, achievement goals, attitudes and intentions to implement the new Greek physical education curriculum. European Physical Education Review, 17(2), 231-253. DOI: $10.1177 / 1356336 X 11413654$

Grivins, M. (2012). Implementation of per capita education funding in the Baltic States. Baltic Journal of European Studies: 2(2), 87-108. DOI: 10.11590/bjes.2012.2.05

Harackiewicz, J. M., Barron, K. E., Pintrich, P. R., Elliot, A. J. \& Thrash, T. M. (2002). Revision of achievement goal theory: Necessary and illuminating. Journal of Educational Psychology, 94, 638-645. Retrieved from:

http://www.unco.edu/cebs/psychology/kevinpugh/motivation_project/resources/ harackiewicz_etal02.pdf

Hulleman, C. S., Schrager, S. M., Bodmann, S. M. \& Harackiewicz, J. M. (2010). A meta analytical review of achievement goal measures: Different labels for the same constructs or different constructs with the same labels? Psychological Bulletin, 136(3), 422-449. http://dx.doi.org/10.1037/a0018947

Järvelä, S., \& Järvenoja, H. (2011). Socially constructed self-regulated learning in collaborative learning groups. Teachers College Records, 113(2), 350-374.

Kangro, A., \& Kangro, I. (2004). Integration of ICT in teacher education and different school subjects in Latvia. Educational Media International, 41(1), 31-37. DOI: $10.1080 / 0952398032000105076$

Karaseva, A., Siibak, A., \& Pruulmann-Vengerfeldt, P. (2015). Relationships between teachers` pedagogical beliefs, subject cultures, and mediation practices of students' use of digital technology. Cyberpsychology: Journal of Psychological Research on Cyberspace, 9(1), no page number. DOI: 10.5817/CP2015-1-6.

Karaseva, A. (2016). Relationship of Internet self-efficacy and online search performance of secondary school teachers. Procedia - Social and Behavioral Sciences (231), 278-285. DOI: 10.1016/j.sbspro.2016.09.103 
Kucsera, J.V., Roberts, R., Walls, S., Walker, J., \& Svinicki, M. (2011). Goal orientation towards teaching (GOTT) scale. Teachers and Teaching: theory and practice, 17(5), 597-610. DOI: 10.1080/13540602.2011.602212

Linnenbrink, E.A., \& Pintrich, P.R. (2003). The role of self-efficacy beliefs in student engagement and learning in the classroom. Reading \& Writing Quarterly: Overcoming Learning Difficulties, 19(2), 119-137. DOI: $10.1080 / 10573560308223$

Linnenbrink, E.A. (2005). The dilemma of performance-approach goals: the use of multiple goal contexts to promote students' motivation and learning. Journal of Educational Psychology, 97(2), 197-213. DOI: 10.1037/0022-0663.97.2.197

Maehr, M. L., \& Zusho, A. (2009). Achievement goal theory: the past, present, and future. In K. R. Wentzel \& A. Wigfield (Eds.), Handbook of motivation at school, 77-104. New York: Routledge.

Mansfield, C., F., Wosnitza, M. \& Beltman, S. (2012). Goals for teaching: Towards a framework for examining motivation of graduating teachers. Australian Journal of Educational \& Developmental Psychology, 12, 21-34. Retrieved from: https://www.newcastle.edu.au/_data/assets/pdf_file/0011/100253/V12_mansfie ld_et_al.pdf

Mägi, E. (2006). Issues in Estonia: The challenge of having fewer children! Thematic dossiers for observatory for the new technologies and education. Retrieved from: http://insight.eun.org/ww/en/pub/insight/thematic-dossiers/articles

Midgley, C., Kaplan, A. \& Middleton, M. (2001). Performance-approach goals: Good for what, for whom, under what circumstances, and at what cost? Journal of Educational Psychology, 93(1), 77-86. DOI: 10.1037//0022-0663.93.1.77

Murayama, K., Elliot, A., J. \& Yamagata, S. (2011). Separation of performanceapproach and performance-avoidance goals: A broader analysis. Journal of Educational Psychology, 103(1), 238-256. DOI: 10.1037/a0021948

Ng, C.-H. (2010). Do career goals promote continuous learning among practicing teachers? Teachers and Teaching: theory and practice, 16(4), 397-422. DOI: $10.1080 / 13540601003754806$ 
Nicholls, J. G., Patashnick, M., \& Nolen, S. B. (1985). Adolescents' theories of education. Journal of Educational Psychology, 77(6), 683-692, DOI: http://dx.doi.org/10.1037/0022-0663.77.6.683.

Nolen, S.B. (1988). Reasons for studying: motivational orientations and study strategies. Cognition and Instruction, 5, 269-287. DOI: 10.1207/s1532690xci0504_2

Nitsche, S., Dickhäuser, O., Fasching, M. S., \& Dresel, M. (2011). Rethinking teachers' goal orientations: Conceptual and methodological enhancements. Learning and Instruction, 21(4), 574-586. DOI: 10.1016/j.learninstruc.2010.12.001

Ottenbreit-Leftwich, A., Glazewski, K. D., Newby, T. J. \& Ertmer, P. A. (2010). Teacher value beliefs associated with using technology: addressing professional and student needs. Computers \& Education, 55, 1321-1335. DOI: 10.1016/j.compedu.2010.06.002

Pajares, M.F. (1992). Teachers` beliefs and educational research: cleaning up a messy construct. Review of Educational Research, 62, 307-332. http://www.jstor.org/stable/1170741

Pintrich, P.R. (2000). Multiple goals, multiple pathways: the role of goal orientation in learning and achievement. Journal of Educational Psychology, 92, 544-555. DOI: $10.1037 / 0022-0663.92 .3 .544$

Plank, S.B., \& Condliffe, B.F. (2013). Pressures of the season: an examination of classroom quality and high-stakes accountability. American Educational Research Journal, 50(5), 1152-1182. DOI: 10.3102/0002831213500691

Popham, W. J. (2001). Teaching to the test? Educational Leadership, 58(6), 16-20. Retrieved from: http://www.ascd.org/publications/educationalleadership/mar01/vol58/num06/Teaching-to-the-Test\%C2\%A2.aspx

Retelsdorf, J., Butler, R., Streblow, L., \& Schiegele, U. (2010). Teachers`goal orientations for teaching: Associations with instructional practices in teaching and burnout. Learning and Instruction, 20, 30-46. DOI: 10.1016/j.learninstruc.2009.01.001 
Retelsdorf, J., \& Günther, C. (2011). Achievement goals for teaching and teachers` reference norms: Relations with instructional practices. Teaching and Teacher education, 27, 1111-1119. DOI: 10.1016/j.tate.2011.05.007

Rieger, O.Y. (2009). Search engine use behaviour of students and faculty: user perceptions and implications for future research. First Monday, 14(12). Retrieved from: http://firstmonday.org/ojs/index.php/fm/article/view/2716/2385

Runnel, P., Pruulman-Vengerfeld, P., \& Reinsalu, K. (2009). Estonian Tiger Leap from post-communism to the information society. Journal of Baltic Studies, 40(1), 29-51. DOI: 10.1080/01629770902722245

Ryan, A.M., \& Shim, S.S. (2008). An exploration of young adolescents' social achievement goals and social adjustment in middle school. Journal of Educational Psychology, 100(3), 672-687. DOI: 10.1037/0022-0663.100.3.672

Selwood, I., \& Pilkington, R. (2005). Teacher workload: Using ICT to release time to teach. Educational Review, 57(2), 163-174. DOI:

\section{$10.1080 / 0013191042000308341$}

Shim, S.S., Cho, Y., \& Cassady, J. (2013). Goal structures: The role of teachers` achievement goals and theories of intelligence. Journal of Experimental Education, 81(1), 84-104. DOI: 10.1080/00220973.2011.635168

Thomson, M. M., \& McIntyre, E. (2013). Prospective teachers` goal orientation: an examination of different teachers` typologies with respect to motivation and beliefs about teaching. Teacher Development, 17(4), 409-430. DOI: $10.1080 / 13664530.2013 .804001$

Van Eekelen, I. M., Vermunt, J. D., \& Boshuizen, H. P. A. (2006). Exploring teachers' will to learn. Teaching and Teacher Education, 22, 408-423. DOI: 10.1016/j.tate.2005.12.001

van Uden, J.M., Ritzen, H. \& Pieters, J.M. (2013). I think I can engage my students. Teachers` perceptions of student engagement and their beliefs about being a teacher. Teaching and Teacher Education, 32, 43-54. DOI: 10.1016/j.tate.2013.01.004 
Watt, H. M. G., \& Richardson, P. W. (2008). Motivations, perceptions, and aspirations concerning teaching as a career for different types of beginning teachers. Learning and Instruction, 18, 408-428. DOI: 10.1016/j.learninstruc.2008.06.002

Webb, M. (2014). Pedagogy with information and communications technologies in transition. Education and Information Technologies, 19(2), 275-294. DOI: 10.1007/s10639-012-9216-x

Woolfolk Hoy, A. (2008). What motivates teachers? Important work on a complex question. Learning and Instruction, 18(5), 492-498. DOI:

10.1016/j.learninstruc.2008.06.007

Yin, R. K. (1993). Applications of case study research. London: Sage. 